\title{
DEVELOPMENT, STRUCTURE, AND SUSTAINABILITY OF SACRAMENTO'S URBAN FOREST (PART II): INTRODUCTION
}

\begin{abstract}
This special issue of the Journal of Arboriculture is the second and final in a series describing the results of an extensive study of the development, structure, and sustainability of the Sacramento, California, urban forest. Scientists from the USDA Forest Service, University of California, and the private sector collaborated on a series of research projects to provide an indepth analysis of the Sacramento area from an ecosystem perspective utilizing the physical, biological, and social science disciplines. As is the policy of the Journal, each paper was sent to two members of the Editorial Committee; publication was based on their review and recommendations. The March 1998 issue of the Journal contains the first five papers describing this project.
\end{abstract}

